\title{
Impacts of Six Bt Rice Lines on Nontarget Rice Feeding Thrips Under Laboratory and Field Conditions
}

\author{
Z. R. AKHTAR, ${ }^{1}$ J. C. TIAN,${ }^{1}$ Y. CHEN, ${ }^{1}$ Q. FANG,${ }^{1}$ C. HU, ${ }^{1}$ M. CHEN,${ }^{2}$ Y. F. PENG,${ }^{3}$ and G. Y. YE ${ }^{1,4}$
}

Environ. Entomol. 39(2): 715-726 (2010); DOI: 10.1603/EN09095

\begin{abstract}
Nontarget impacts of six transgenic Bt rice lines (expressing the Cryl Ab or CrylAb/ CrylAc protein) on the thrips, Stenchaetothrips biformis (Bagnall), attacking the rice seedling and tillering stages, were evaluated under laboratory and field conditions. Laboratory results showed relatively longer larval, pupal development and preoviposition durations of S. biformis. Although it had a shorter oviposition period, female adult longevity and less total laid eggs were found when fed on some tested $B t$ rice in comparison to non- $B t$ controls. S. biformis population dynamics in $B t$ and non- $B t$ plots were monitored using the plastic bag and beat plate methods. In the field, the temporal patterns of S. biformis population changes were similar between tested Bt rice lines and their respective control; however, the total number of $S$. biformis individuals collected from the $B t$ plots were significantly less or the same, varying from variety to variety, compared with those from the non-Bt plots. ELISA results showed that the Bt insecticidal protein could be transferred from $B t$ rice to the thrips, and the concentrations of the protein in rice leaves and thrips were not significantly correlated with some important biological parameters of the thrip. In addition, the potential effects of $B t$ rice on the abundance of S. biformis candidate predators are also discussed. In conclusion, our results show that the six $B t$ rice lines assessed may be less preferable host plants to $S$. biformis at the individual and population levels in comparison to the non-Bt rice plants.
\end{abstract}

KEY WORDS Bt rice, nontarget insect, rice thrip, Stenchaetothrips biformis

Rice (Oryza sativa L.) is the world's most important food crop and a primary source of food for more than one half of the world's population. More than $90 \%$ of the world's rice is grown and consumed in Asia, where $60 \%$ of the world population lives (Khush 2005). However, it is crucial to increase rice production to meet the increasing needs of the projected human population of 2030 , so $40 \%$ more rice must be produced by using various conventional and biotechnological approaches with the ultimate goal to develop rice varieties with higher yield potential, greater yield stability, and durable resistance against diseases and insects (Khush 2005).

Stenchaetothrips biformis (Bagnall) (Thrips oryzae Williams) (Thysanoptera: Thripiade) with a raspingsucking mouthpart is known to attack rice in different parts of the world including Europe, South America, and Asia. S. biformis feeds on young plants by lacerating the green tissue of leaves, and outbreaks have often been reported in China, India, and Bangladesh

\footnotetext{
${ }^{1}$ State Key Laboratory of Rice Biology, Ministry of Agriculture Key Laboratory of Molecular Biology of Crop Pathogens and Insects, Institute of Insect Sciences, Zhejiang University, Hangzhou 310029, China.

${ }^{2}$ Department of Entomology, Cornell University, New York State Agricultural Experiment Station, Geneva, NY 14456.

${ }^{3}$ State Key Laboratory for Biology of Plant Diseases and Insect Pests, Institute of Plant Protection, Chinese Academy of Agricultural Sciences, Beijing 100094, China.

${ }^{4}$ Corresponding author, e-mail: chu@zju.edu.cn.
}

(Nugaliyadde and Heinrichs 1984, Dale 1994, Pathak and Khan 1994). Since the 1990s, numerous rice genotypes expressing various insect-active crystal (Cry) proteins derived from the bacterium Bacillus thuringiensis Berliner $(B t)$ (referred as $B t$ rice hereafter) have been developed with resistance to one or more rice lepidopterous pests, the most important of which are the yellow stem borer, Scirpophaga incertula (Walker) (Lepidoptera: Pyralidae), the striped stem borer, Chilo suppressalis (Walker) (Lepidoptera: Crambidae), and the leaffolder, Cnaphalocrocis medinalis (Guenée) (Lepidoptera: Pyralidae) (reviewed by Breitler et al. 2004, High et al. 2004, Ramesh et al. 2004, Riaz et al. 2006, Tang et al. 2006, Rahman et al. 2007, Chen et al. 2008). Since the late 1990s, field trials of various $B t$ rice genotypes expressing Cryl Ab protein (Shu et al. 2000; Ye et al. 2001a, 2003), a fusion protein of CrylAb/Cry1Ac (Ye et al. 2001b), Cry2A CrylAc, and Cry9C (Chen et al. 2008), CrylC (Tang et al. 2006), and a fusion protein of CrylAc/CpTI (Han et al. 2007) have been conducted in China. Likewise, field trials started in Pakistan (Bashir et al 2004a, b, 2005; Rahman et al. 2007). Scientifically sound risk assessments of $B t$ rice impacts on the important nontarget pests are critically needed before the commercial releases of $B t$ rice.

With the increasing area of two major insect-resistant genetically modified (IRGM) transgenic crops, $B t$ cotton and $B t$ maize, grown in several countries world- 
wide, it is commonly postulated that $B t$ crops and their expression products, activated $B t$ insecticidal proteins, are specifically efficacious against a limited number of target insects, whereas limited effects have been reported for many nontarget arthropods (Shelton et al. 2002, O'Callaghan et al. 2005, Marvier et al. 2007, Wolfenbarger et al. 2008). However, the potential adverse effects of IRGM crops on nontarget arthropods, as part of the environmental risk assessment process, needs to be carefully evaluated before the decision is made to release novel IRGM crops commercially (Romeis et al. 2008). A major environmental concern about the deployment of $B t$ rice is its potential to adversely affect nontarget arthropods, including economically important nontarget herbivores, parasitoids, and predators. Previously, many trials have assessed the potential impacts of $B t$ rice on nontarget herbivores, parasitoids, predators, and soil-dwelling detritivores (reviewed by Chen et al. 2006a, Cohen et al. 2008) under laboratory and field conditions, some over multiple years and locations. In general, no significant negative effects of $B t$ rice on nonlepidopterous herbivores, parasitoids, predators, or soil arthropods have been detected, as measured by indicators of fitness, population density and dynamics, and biodiversity indices, except when parasitoids used Bt-intoxicated target insects as hosts (Chen et al. 2006a, 2009; Rahman et al. 2007; Cohen et al. 2008; Tian et al. $2008)$. Effects of $B t$ rice on nontarget herbivores have been focused on several piercing-sucking species including the planthoppers, Nilaparvata lugens (Stål), Sogatella furcifera (Horvath), and Laodelphax striatella (Fallén) (Homoptera: Delphacidae), and the leafhoppers Nephotettix cincticeps (Uhler) and N. virescens (Distant) (Homoptera: Cicadellidae) because $B t$ proteins may be ingested by these nontarget insects and transported to their natural enemies through tritrophic interactions (Chen et al. 2005, 2006b, 2007, 2009; Bai et al. 2006). No adverse effects on the fitness and population densities of the planthoppers and leafhoppers were observed under laboratory and field conditions in previous studies (Bernal et al. 2002; Liu et al. 2002, 2007; Chen et al. 2003, 2004, 2006b; Fu et al. 2003; Bai et al. 2006; Zhou et al. 2006; Tan et al. 2006 ), except one case in which $N$. cincticeps actually performed better on $B t$ rice KMD1 and KMD2 under laboratory and field conditions (Zhou et al. 2005). However, the impact of $B t$ rice on nontarget organisms was evaluated either in the laboratory or in the field with transplants. None of the previous studies have paid attention to one of the most vulnerable growing stage of rice: rice seedlings. Additionally, the effects of $B t$ rice on rice thrips, which are also important nontarget herbivores on $B t$ rice, have not yet been vigorously evaluated.

In this study, the potential impacts of $B t$ rice on $S$. biformis developmental time, reproduction, and population dynamics were evaluated on six different $B t$ rice lines under laboratory and field conditions based on tier-based risk assessment (Romeis et al. 2008). Information gathered from this study can also be extended to the environmental risk assessment processes of other $B t$ crops and therefore can bolster the adoption of Bt crops and can be a step toward the commercialization of $B t$ rice.

\section{Materials and Methods}

Plant Materials. Three groups of $B t$ rice lines, together with their corresponding non- $B t$ parental rice cultivars, were used. The first was Huachi 2000 B1 (B1) and Huachi 2000 B6 (B6) with the gene encoding CrylAb protein, of which its parental control was indica cultivar Jiazao 935. Both B1 and B6 were derived from KMD1 through conventional breeding (Chen et al. 2004). The second was TT9-3 and TT9-4 expressing a fused protein of CrylAb/CrylAc, of which its parental control was indica cultivar IR72 (Ye et al. 2001b). The third was KMD1 and KMD2 expressing CrylAb protein, of which its parental control was japonica cultivar Xiushui 11 (Ye et al. 2001a). For laboratory experiments, the pregerminated seeds of each tested rice entry were sown in the seedling bed in a greenhouse with fine mesh to avoid any insect attack. For field experiments, rice seeds and their seedlings of each tested rice entry were sown and transplanted in the field at the Experimental Farm of Zhejiang University, Hangzhou $\left(120.12^{\circ} \mathrm{E}, 30.13^{\circ} \mathrm{N}\right)$, China.

Insects. Stenchaetothrips biformis were collected from different non- $B t$ rice fields in May 2008 at the Experimental Farm of Zhejiang University, Hangzhou, China, using the plastic bag method: taking out the whole plant and putting it into a bag. Adult thrips were collected from rice plants using a camel hair brush ( size 0 ) or suction tube as necessary and reared on susceptible rice variety, Taichung Native 1 (TN1), (Nugaliyadde and Heinrichs 1984) seedlings in glass tubes ( 38 by $250 \mathrm{~mm}$ ). Each glass tube was filled with $5 \mathrm{ml}$ Kimura B nutrient solution $\left[0.4 \mathrm{M}\left(\mathrm{NH}_{4}\right)_{2} \mathrm{SO}_{4}\right.$ $0.09 \mathrm{M} \mathrm{K}_{2} \mathrm{SO}_{4}, 0.37 \mathrm{M} \mathrm{Ca}\left(\mathrm{NO}_{3}\right)_{2}, 0.56 \mathrm{M} \mathrm{MgSO}_{4}, 0.18$ $\mathrm{M} \mathrm{KNO}_{3}, 0.18 \mathrm{M} \mathrm{KH}_{2} \mathrm{PO}_{4}, 0.02 \mathrm{M} \mathrm{Fe}$ (II)-ethylenediamineteraacetic acid (EDTA), $0.01 \mathrm{M} \mathrm{H}_{3} \mathrm{BO}_{3}, 0.01 \mathrm{M}$ $\mathrm{ZnSO}_{4}, 0.01 \mathrm{M} \mathrm{CuSO}, 0.05 \mathrm{M} \mathrm{MnSO}, 0.005 \mathrm{M}$ $\mathrm{Na}_{2} \mathrm{MoO}_{4}$, and $0.002 \mathrm{M} \mathrm{CoSO}_{4}$ ] (Zhou and Shi 2007). The tubes were covered with nylon mesh. The rice seedlings and its nutrient solution were renewed every 5 and $2 \mathrm{~d}$, respectively. The thrip colonies were reared in an insect-rearing chamber at $27 \pm 1^{\circ} \mathrm{C}, 75$ $80 \% \mathrm{RH}$, and a photoperiod of 16: $8 \mathrm{~h}$ (light: dark).

Laboratory Experiments. Stenchaetothrips biformis developmental duration on each group of tested $B t$ rice lines together with their non- $B t$ parental cultivar was measured. For each tested entry, 32 newly hatched (1-12 h old) larvae were individually placed on the leaves of rice seedlings (two- to three-leave stage) in glass tubes ( 38 by $250 \mathrm{~mm}$ ). Each seedling was supplied with $2 \mathrm{ml}$ Kimura B nutrient solution and covered with fine nylon mesh for ventilation. The survival and development were observed and determined daily until adults emerged and died according to the following method: to locate the larvae on leaf surface or inside unopened leaves, we observed the seedlings against the light (Hsu et al. 1978), took out 
the seedlings, and collected larvae using the suction tube. Each larva was observed in a petri dish under a microscope to determine its stage by its changing color and behavior (Hsu et al. 1978, Dale 1994).

To compare the reproduction capacity differences of $S$. biformis between $B t$ rice and its non-Bt control, S. biformis preoviposition period, oviposition period, oviposition rate, and total number of eggs laid by a female adult on each tested $B t$ rice line together with their non- $B t$ control cultivar were studied. Before the formal experiment, for each tested line, 10 newly hatched (1-12 h old) larvae were reared on a rice seedling (two- to three-leaf stage) contained in a glass tube until adults emerged, and there were 10 tubes with $100 \mathrm{~S}$. biformis prepared. After adults emerged, S. biformis females and males were paired and allowed to mate freely for $1 \mathrm{~d}$. One pair of mated S. biformis was introduced into a glass tube contained a rice seedling with $2 \mathrm{ml} \mathrm{Kimura} \mathrm{B} \mathrm{nutrient} \mathrm{solution.} \mathrm{Thirty-two} \mathrm{pairs}$ were tested for each rice line. S. biformis male adults were removed from the tubes $24 \mathrm{~h}$ after the introduction. For each tested line, the number of eggs laid by each female adult on each seedling was observed and counted daily until all female adults stopped laying eggs. We counted the number of eggs on each seedling by observing it against light, because eggs are clearly visible under the light (Hsu et al. 1978). The laboratory experiments were conducted in the insect chamber under the same environmental conditions as described above. Rice seedlings and the nutrient solutions were renewed daily.

Field Planting. The field experiments were conducted in 2008 at the Experimental Farm of Zhejiang University, Hangzhou, China, where there are usually two rice production seasons (one from the first period of April to July and another from the late period of June to October) or only one rice production season (from May to August). Bt and non-Bt control rice plants tested were sown and transplanted in three batches depending on their biological traits. The first batch for indica Bt rice lines (B1 and B6) together with its control Jiazao935 was sown on 30 March and transplanted on 1 May. The second batch for indica Bt rice lines (TT9-3 and TT9-4) together with its control IR72 was sown on 30 April and transplanted on 30 May. The third batch for japonica Bt rice lines (KMD1 and KMD2) together with its control Xiushuill was sown on 20 June and transplanted on 20 July. All of the seedling bed fields and the transplanted fields were divided into nine experimental plots in a 3 (treatments) (two $B t$ lines versus non- $B t) \times 3$ (replications) completely randomized design. For the seedling bed field, each experimental plot was 20 by $25 \mathrm{~m}^{2}$, and each plot was bordered on all sides by a unsown 50 -cm-wide earthen walkway. For the transplant field, each experimental plot was 20 by $25 \mathrm{~m}^{2}$, and each plot was bordered on all sides by a unplanted 50-cm-wide earthen walkway. Seedlings were hand transplanted at one seedling per hill spaced 16.5 by $16.5 \mathrm{~cm}$ apart. The entire experiment field was surrounded by five border rows of non- $B t$ control plants. Normal cultural practices for growing rice, such as fertilization and irriga- tion, were followed during the course of the experiment, except that no insecticides were applied after sowing and transplanting.

Plastic Bag Sampling. Following Moura et al. (2003) and Bacci et al. (2008), in each test plot during the rice seedling stage, 30 seedlings were selected randomly along the diagonal transect in each tested plot, and 1 seedling was cut from the base and put into a plastic bag. In addition, 30 plants were also sampled at random along the diagonal transect in each test plot after the transplantation, and three young leaves along with a part of stem for each plant were cut and put carefully into a plastic bag. All sample seedlings were brought to the laboratory, and the total number of larvae and adults was counted by opening the leaves using forceps and dissecting needles under a dissecting microscope. In the seeding bed field and the transplanted field, the sampling was conducted weekly except if it was raining. It was difficult to find the thrips after a rain because they prefer dry weather (Hsu et al. 1978, Husain 1982).

Beat Plate Sampling. Individual rice plants were sampled with a white porcelain plate ( 36 by 46 by 3.5 $\mathrm{cm}$ ), modified from Joost and Riley (2004) and Bacci et al. (2008). On each sampling date, 30 plants were sampled at random along a diagonal line of each tested plot either during the seedling stage or the stage after transplantation. When sampling, the plate was held at a $45^{\circ}$ angle to the ground, and a single plant was carefully grasped by the lower stem and quickly bent into the plate. The sampled plant was beaten vigorously against the side of the plate for a 4 - to 5 -s period $(\approx 13-15$ beats $)$. The plant was removed, and the dislodged larvae and adults of the thrips inside the plate were counted with the aid of a magnifying glass. After each sample, the inside of the plate was wiped clean with a paper towel.

Quantification of $\boldsymbol{B t}$ Insecticidal Protein. Stenchaetothrips biformis adults and rice leaves (first and second leaf from the flag leaf) were collected, respectively, in $B t$ and non-Bt control rice fields at the seedling stage (15 d after sowing) and the tillering stage (60 d after transplantation). All samples were frozen at $-70^{\circ} \mathrm{C}$ immediately after being transferred into 1.5-ml Eppendorf tubes. To assay the level of CrylAb or Cry1Ab/CrylAc, ELISA was carried out using a QualiPlate kit for CrylAb/CrylAc (EnviroLogix, Portland, OR). According to the protocol of the kit, samples (three replications for rice leaves and S. biformis) were homogenized in $0.2 \mathrm{ml}$ phosphatebuffered saline solution in $0.05 \%$ Tween-20 and centrifuged for $5 \mathrm{~min}$ at $12,000 \mathrm{~g}$, and total protein concentration was determined according to the method of Bradford: $0.1 \mu \mathrm{g}$ of protein per rice leaf sample and 10 $\mu \mathrm{g}$ of protein per S. biformis sample were loaded per well. The spectrophotometric measurements were taken using a multidetection microplate reader (BioTek, Winooski, VT) reading at $450 \mathrm{~nm}$. Purified CrylAb insecticidal protein (EnviroLogix, Portland, OR) at concentrations of $0,0.625,1.25,2.5,5$, and 10 $\mathrm{ng} / \mathrm{ml}$ were used for calibrations. 
Table 1. The mean concn of $B t$ insecticidal protein in rice leaves and $S$. biformis adults collected from Bt and non-Bt plots at Hangzhou, China

\begin{tabular}{|c|c|c|c|c|}
\hline \multirow[b]{2}{*}{ Rice genotype } & \multicolumn{2}{|c|}{ Seedling stage } & \multicolumn{2}{|c|}{ Tillering stage } \\
\hline & $\begin{array}{l}\text { Rice leaves } \\
(\mu \mathrm{g} / \mathrm{mg} \text { TSP })\end{array}$ & $\begin{array}{c}\text { Thrips } \\
\text { (ng/mg TSP) }\end{array}$ & $\begin{array}{l}\text { Rice leaves } \\
(\mu \mathrm{g} / \mathrm{mg} \text { TSP })\end{array}$ & $\begin{array}{c}\text { Thrips } \\
\text { (ng/mg TSP) }\end{array}$ \\
\hline \multicolumn{5}{|l|}{ Group 1 (indica) } \\
\hline Bl (CrylAb) & $1.42 \pm 0.04$ & $45.8 \pm 10.8$ & $2.69 \pm 0.08$ & $59.8 \pm 7.6$ \\
\hline B6 (CrylAb) & $1.18 \pm 0.08$ & $45.6 \pm 5.8$ & $2.22 \pm 0.24$ & $59.6 \pm 3.5$ \\
\hline Jiazao935 & n.d. & n.d. & n.d. & n.d. \\
\hline \multicolumn{5}{|l|}{ Group 2 (indica) } \\
\hline TT9-3 (CrylAb/CrylAc) & $0.20 \pm 0.06$ & $4.00 \pm 0.60$ & $0.41 \pm 0.07$ & $6.25 \pm 0.43$ \\
\hline TT9-4 (CrylAb/CrylAc) & $0.18 \pm 0.03$ & $2.71 \pm 0.42$ & $0.38 \pm 0.04$ & $4.84 \pm 0.32$ \\
\hline IR72 & n.d. & n.d. & n.d. & n.d. \\
\hline \multicolumn{5}{|l|}{ Group 3 (japonica) } \\
\hline KMD1 (CrylAb) & $2.77 \pm 0.08$ & $127.2 \pm 35.9$ & $4.98 \pm 0.06$ & $324.3 \pm 28.9$ \\
\hline KMD2 (CrylAb) & $2.29 \pm 0.46$ & $136.2 \pm 32.7$ & $4.67 \pm 0.12$ & $334.3 \pm 26.3$ \\
\hline Xiushuill & n.d. & n.d. & n.d. & n.d. \\
\hline
\end{tabular}

Data are means $\pm \mathrm{SE}(n=3)$

TSP, total soluble protein; n.d., not detectable.

Data Analysis. Survival curves for S. biformis reared on $B t$ and non- $B t$ rice were compared using the Wilcoxon test for homogeneity, and the seasonal densities of S. biformis over the whole sampling stage were analyzed using repeated-measures analysis of variance (ANOVA) in the SAS LIFETEST procedure, conducted using SAS version 6 (SAS Institute 1996). Data on S. biformis developmental duration and reproduction parameters were analyzed using one-way ANOVA and Tukey's multiple-range test. To avoid pseudoreplication, each plot was considered as one experimental unit/replicate. Therefore, for the density measurement on each sampling date, the mean overall number of plants collected in each plot was determined. The log-transformed plot means were used for statistical analyses (Sisterson et al. 2004), but untransformed means are presented. All statistical analyses including correlation analysis but not survival and field data analyses were conducted using the DPS package (version 8.01 for windows) (Tang and Feng 2007). For all tests, $\alpha=0.05$.

\section{Results}

$B t$ Insecticidal Protein Detection in Bt Rice Leaves and Thrips. Bt insecticidal protein detection using ELISA indicated that the mean concentrations of CrylAb or CrylAb/CrylAc detected were variable depending on $B t$ rice types and their developmental stages (Table 1). Concentrations of $B t$ insecticidal protein both in KMD1 and KMD2 were higher than those in B1, B6, TT9-3 and TT9-4. Additionally, concentrations of $B t$ insecticidal protein for all tested $B t$ rice lines at the seedling stage were lower than those at the tillering stage.

$B t$ insecticidal protein was clearly detected using ELISA in S. biformis adults collected from all tested Bt rice plots, and its concentration in thirp adults fed on each $B t$ rice line was lower than that on leaves of the corresponding lines (Table 1). However, no Bt insecticidal protein was detected in thrip adults collected from non- $B t$ rice plots. Concentrations of $B t$ insecti- cidal protein in different $B t$ rice-fed thrip adults were dependent on $B t$ rice types and their developmental stages. Concentrations of $B t$ insecticidal protein in thrip adults were the highest as fed on KMD1 and KMD2 and the lowest as fed on TT9-3 and TT9-4. By comparison with the seedling stage, concentrations of $B t$ insecticidal protein in thrip adults for all tested $B t$ rice lines were higher at the tillering stage.

In addition, a positive linear relationship between the concentration of $B t$ insecticidal protein in thrip adults $(y)$ and that in $B t$ rice leaves $(x)$ both at the rice seedling stage $(y=-11.2083+53.3283 x ; F=55.48$; $P=0.0017 ; r=0.9658)$ and tillering stage $(y=$ $-56.3350+73.4267 x ; F=31.65 ; P=0.0049 ; r=0.9422)$ was found. Thus, it is clear that as more $B t$ insecticidal protein exists in $B t$ rice leaves the more $B t$ insecticidal protein is transferred to the herbivore S. biformis.

Survival and Development Under Laboratory Conditions. The survival probability of S. biformis was unaffected by rice type (B1, B6, and Jiazao $935: \chi^{2}=$ $0.2432 ; \mathrm{df}=2 ; P=0.8855 ;$ TT9-3, TT9-4, and IR72: $\chi^{2}=2.0963 ; \mathrm{df}=2 ; P=0.3506$; for KMD1, KMD2, and Xiushui 11: $\chi^{2}=0.7718$; $\mathrm{df}=2 ; P=0.6798 ;$ Fig. 1 ).

Several developmental parameters including larval duration, total duration of prepupae and pupae, and their total duration of S. biformis on all tested Bt rice lines and their respective non- $B t$ controls are shown in Table 2. For the group with $B t$ rice (B1 and B6) and non- $B t$ control Jiazao 935, larval duration $(F=67.81$; $\mathrm{df}=2,86 ; P<0.001$ ), prepupal and pupal duration $(F=136.22 ; \mathrm{df}=2,83 ; P<0.001)$, and their total duration $(F=305.69$; $\mathrm{df}=2,83 ; P<0.001)$ were significantly affected by rice type. Therefore, for the group with $B t$ rice (TT9-3 and TT9-4) and non-Bt control IR72 (larval duration: $F=12.60 ; \mathrm{df}=2,86 ; P<$ 0.001; prepupal and pupal duration: $F=56.78$; $\mathrm{df}=$ 2,$81 ; P<0.001$; total duration: $F=42.44 ; \mathrm{df}=2,81 ; P<$ 0.001 ) and for the group with $B t$ rice (KMD1 and KMD2) and non- $B t$ control Xiushui 11 (larval duration: $F=70.04 ; \mathrm{df}=2,84 ; P<0.001 ;$ prepupal and pupal duration: $F=78.56 ; \mathrm{df}=2,78 ; P<0.001$; total duration: $F=82.63 ; \mathrm{df}=2,78 ; P<0.001)$. By comparison, with 


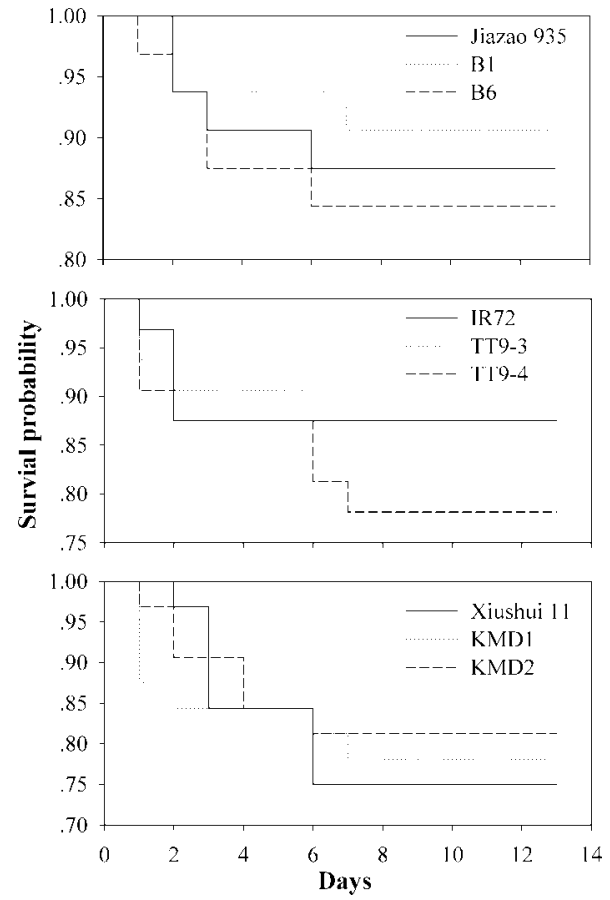

Fig. 1. Survival curves of $S$. biformis larvae reared on $B t$ and non- $B t$ rice.

non-Bt control Jiazao 935, larval duration, prepupal and pupal duration, and total duration of this thrip fed on $B t$ rice $\mathrm{B} 1$ and $\mathrm{B} 6$ were significantly longer, except that there was no significant difference in prepupal and pupal duration between B6 and Jiazao 935 (group 1 in Table 2). When fed on Bt rice TT9-3 but not TT9-4, larval duration, prepupal and pupal duration, and total duration of this thrip became significantly longer by comparison with non-Bt control IR72 (group 2 in Table 2). Similarly, all of larval duration, prepupal and pupal duration, and total duration of the thrips fed on $B t$ rice KMD1 and KMD2 were significantly longer than those on the non-Bt control Xiushui 11 (group 3 in Table 2).
Additionally, by comparison with their respective non-Bt controls, total durations of S. biformis on Bt rice B1, B6, TT9-3, TT9-4, KMD1, and KMD2 were prolonged by $30.71,7.66,15.68,4.08,20.29$, and $21.48 \%$, respectively, which was not significantly correlated with the corresponding mean concentrations of $B t$ insecticidal protein in rice leaves (seedling stage: $r=0.5431<r_{0.05}=0.8114$; tillering stage: $r=$ $0.5507<r_{0.05}=0.8114$ ) and thrips (seedling stage: $r=0.4619<r_{0.05}=0.8114$; tillering stage: $r=$ $\left.0.4016<r_{0.05}=0.8114\right)$.

Reproduction Under Laboratory Conditions. Several reproduction parameters including the preoviposition period, oviposition period, female adult longevity, oviposition rate, and fecundity of S. biformis on all tested $B t$ rice lines and their respective non- $B t$ controls are shown in Table 3. In group 1, Bt rice B1 and B6 together with their non-Bt control Jiazao 935, S. biformis preoviposition period $(F=142.81$; $\mathrm{df}=$ $2,95 ; P<0.001)$, oviposition period $(F=327.17 ; \mathrm{df}=2,95$; $P<0.001)$, female adult longevity $(F=3.16 ; \mathrm{df}=2,95$; $P=0.0468)$, oviposition rate $(F=205.32 ; \mathrm{df}=2,95 ; P<$ $0.001)$, and fecundity $(F=473.45 ; \mathrm{df}=2,95 ; P<0.001)$ were significantly affected by rice type. Similarly, rice type significantly affected S. biformis preoviposition and oviposition periods, female adult longevity, oviposition rate and fecundity in group 2 with $B t$ rice (TT9-3 and TT9-4) and non-Bt control IR72 (preoviposition period: $F=53.14$; $\mathrm{df}=2,95 ; P<0.001$; oviposition period: $F=123$; $\mathrm{df}=2,95 ; P<0.001$; female adult longevity: $F=53.17$; $\mathrm{df}=2,95 ; P=0.046$; oviposition rate: $F=43.07 ; \mathrm{df}=2,95 ; P<0.001$; fecundity: $F=80.66 ; \mathrm{df}=2,95 ; P<0.001)$ and the group 3 with $B t$ rice (KMD1 and KMD2) and non-Bt control Xiushuill (preoviposition period: $F=72.56 ; \mathrm{df}=2,95 ; P<$ 0.001 ; oviposition period: $F=386.89$; $\mathrm{df}=2,95 ; P<0.001$; female adult longevity: $F=81.98 ; \mathrm{df}=2,95 ; P<0.001$; oviposition rate: $F=50.58 ; \mathrm{df}=2,95 ; P<0.001$; fecundity: $F=143.46 ; \mathrm{df}=2,95 ; P<0.001)$.

When S. biformis were fed on Bt rice $\mathrm{B} 1$ and $\mathrm{B} 6$, the preoviposition period was lengthened; the oviposition period and female adult longevity were shortened; and the oviposition rate and fecundity were significantly

Table 2. Developmental duration of $S$. biformis reared on $B t$ and non-Bt rice

\begin{tabular}{|c|c|c|c|}
\hline \multirow{2}{*}{ Rice genotype } & \multicolumn{3}{|c|}{ Developmental duration (d) } \\
\hline & Larvae & Prepupa and pupa & Total \\
\hline \multicolumn{4}{|l|}{ Group 1 (indica) } \\
\hline Bl (CrylAb) & $4.56 \pm 0.09 \mathrm{a}(n=30)$ & $6.22 \pm 0.07 \mathrm{a}(n=29)$ & $10.78 \pm 0.42 \mathrm{a}(n=29)$ \\
\hline B6 (CrylAb) & $3.63 \pm 0.09 \mathrm{~b}(n=28)$ & $4.47 \pm 0.09 \mathrm{~b}(n=27)$ & $8.09 \pm 0.73 \mathrm{~b}(n=27)$ \\
\hline Jiazao935 & $3.22 \pm 0.07 \mathrm{c}(n=29)$ & $4.25 \pm 0.11 \mathrm{~b}(n=28)$ & $7.47 \pm 0.5 \mathrm{lc}(n=28)$ \\
\hline \multicolumn{4}{|l|}{ Group 2 (indica) } \\
\hline TT9-3 (CrylAb/CrylAc) & $4.72 \pm 0.08 \mathrm{a}(n=29)$ & $6.44 \pm 0.09 \mathrm{a}(n=28)$ & $11.16 \pm 0.72 \mathrm{a}(n=28)$ \\
\hline TT9-4 (CrylAb/CrylAc) & $4.31 \pm 0.08 \mathrm{~b}(n=28)$ & $5.50 \pm 0.09 \mathrm{~b}(n=25)$ & $9.81 \pm 0.86 \mathrm{~b}(n=25)$ \\
\hline IR72 & $4.19 \pm 0.07 \mathrm{~b}(n=29)$ & $5.22 \pm 0.07 \mathrm{~b}(n=29)$ & $9.41 \pm 0.80 \mathrm{~b}(n=29)$ \\
\hline \multicolumn{4}{|l|}{ Group 3 (japonica) } \\
\hline KMD1 (CrylAb) & $5.31 \pm 0.08 \mathrm{a}(n=29)$ & $6.56 \pm 0.09 \mathrm{a}(n=27)$ & $11.88 \pm 0.87 \mathrm{a}(n=27)$ \\
\hline KMD2 (CrylAb) & $5.50 \pm 0.09 \mathrm{a}(n=29)$ & $6.56 \pm 0.09 \mathrm{a}(n=28)$ & $12.06 \pm 0.98 \mathrm{a}(n=28)$ \\
\hline Xiushuil1 & $4.22 \pm 0.07 \mathrm{~b}(n=27)$ & $5.25 \pm 0.08 \mathrm{~b}(n=24)$ & $9.47 \pm 0.84 \mathrm{~b}(n=24)$ \\
\hline
\end{tabular}

In the parentheses after rice types, it is the type of $B t$ protein expressed by the rice line. Data are means \pm SE $(n$ showed in the parentheses after the data). Values followed by different lowercase letters within a column for each group are significantly different (ANOVA,Tukey's multiple-range test, $P<0.05)$. 
Table 3. Several reproductive parameters of $S$. biformis reared on $B t$ and non-Bt rice

\begin{tabular}{|c|c|c|c|c|c|}
\hline Rice genotype & $\begin{array}{l}\text { Preoviposition } \\
\text { period }(\mathrm{d})\end{array}$ & $\begin{array}{l}\text { Oviposition } \\
\text { period }(\mathrm{d})\end{array}$ & $\begin{array}{l}\text { Female adult } \\
\text { longevity }(\mathrm{d})\end{array}$ & $\begin{array}{l}\text { Oviposition rate } \\
(\text { egg no./female/d) }\end{array}$ & $\begin{array}{l}\text { Fecundity (total } \\
\text { egg no./female) }\end{array}$ \\
\hline \multicolumn{6}{|l|}{ Group 1 (indica) } \\
\hline $\mathrm{B} 1(\mathrm{CrylAb})$ & $4.84 \pm 0.07 \mathrm{a}$ & $15.41 \pm 0.11 \mathrm{c}$ & $27.84 \pm 0.32 b$ & $1.57 \pm 0.03 \mathrm{c}$ & $24.1 \pm 0.5 c$ \\
\hline B6 (CrylAb) & $3.66 \pm 0.09 b$ & $18.72 \pm 0.14 b$ & $27.88 \pm 0.13 b$ & $2.30 \pm 0.03 b$ & $43.0 \pm 0.5 b$ \\
\hline Jiazao935 & $3.16 \pm 0.07 \mathrm{c}$ & $19.84 \pm 0.14 \mathrm{a}$ & $28.53 \pm 0.14 \mathrm{a}$ & $2.46 \pm 0.04 \mathrm{a}$ & $48.7 \pm 0.8 \mathrm{a}$ \\
\hline \multicolumn{6}{|l|}{ Group $2($ indica $)$} \\
\hline TT9-3 (CrylAb/CrylAc) & $4.59 \pm 0.09 \mathrm{a}$ & $15.84 \pm 0.12 b$ & $24.31 \pm 0.08 \mathrm{c}$ & $2.21 \pm 0.04 b$ & $34.9 \pm 0.6 \mathrm{~b}$ \\
\hline TT9-4 (CrylAb/CrylAc) & $3.56 \pm 0.09 \mathrm{~b}$ & $18.22 \pm 0.12 \mathrm{a}$ & $25.41 \pm 0.09 \mathrm{~b}$ & $1.98 \pm 0.04 \mathrm{c}$ & $36.1 \pm 0.6 \mathrm{~b}$ \\
\hline IR72 & $3.41 \pm 0.09 \mathrm{~b}$ & $18.00 \pm 0.12 \mathrm{a}$ & $25.84 \pm 0.14 \mathrm{a}$ & $2.55 \pm 0.05 \mathrm{a}$ & $45.8 \pm 0.8 \mathrm{a}$ \\
\hline \multicolumn{6}{|l|}{ Group 3 (japonica) } \\
\hline KMD1 (CrylAb) & $4.03 \pm 0.08 b$ & $13.66 \pm 0.13 \mathrm{c}$ & $24.56 \pm 0.09 \mathrm{~b}$ & $2.23 \pm 0.04 b$ & $30.5 \pm 0.4 \mathrm{~b}$ \\
\hline KMD2 (CrylAb) & $4.56 \pm 0.09 \mathrm{a}$ & $14.81 \pm 0.12 b$ & $24.25 \pm 0.08 c$ & $2.13 \pm 0.04 \mathrm{~b}$ & $31.4 \pm 0.6 \mathrm{~b}$ \\
\hline Xiushuill & $3.19 \pm 0.07 \mathrm{c}$ & $18.28 \pm 0.11 \mathrm{a}$ & $25.69 \pm 0.08 \mathrm{a}$ & $2.38 \pm 0.03 \mathrm{a}$ & $43.6 \pm 0.5 \mathrm{a}$ \\
\hline
\end{tabular}

In the parentheses is the type of Bt protein expressed by the rice line. Data are means $\pm \mathrm{SE}(n=32)$. Values followed by different lowercase letters within a column for each group are significantly different (ANOVA, Tukey's multiple-range test, $P<0.05$ )

reduced by comparison with the control Jiazao935 (group 1 in Table 3). When S. biformis fed on Bt rice, TT9-3, the preoviposition period became significantly longer, the oviposition period and female adult longevity were shorter by comparison with the control IR72. The oviposition rate and fecundity became significantly lower by comparison with control IR72 when S. biformis fed on Bt rice TT9-3 and TT9-4 (group 2 in Table 3). Similarly, as S. biformis fed on Bt rice KMD1 and KMD2, the preoviposition period was lengthened, the oviposition period and female adult longevity were shortened, and the oviposition rate and fecundity were significantly decreased by comparison with non-Bt control Xiushuill (group 3 in Table 3 ).

Additionally, by comparison with their respective non-Bt controls, the fecundity of S. biformis on Bt rice B1, B6, TT9-3, TT9-4, KMD1, and KMD2 were reduced by $50.51,11.70,23.00,21.18,30.05$, and $27.98 \%$, respectively, which was not significantly correlated with the corresponding mean concentrations of $\mathrm{Bt}$ insecticidal protein in rice leaves (seedling stage: $r=0.2914<r_{0.05}=$ 0.8114; tillering stage: $r=0.2890<r_{0.05}=0.8114$ ) and thrips (seedling stage: $r=0.1718<r_{0.05}=0.8114$; tillering stage: $r=0.1332<r_{0.05}=0.8114$ ).

Field Population Density Sampled Using the Plastic Bag Method. Data from the plastic bag samplings indicated that the temporal patterns of population changes of S. biformis were similar in the Bt and non-Bt plots, although there was significant difference in the density of the thrip at some sampling dates for each group with $B t$ rice lines and their respective non- $B t$ control (left side of Figs. 2-4). In the group of $B t$ rice B1 and B6 together with their non-Bt control Jiazao 935 , the density of the $S$. biformis population was significantly affected by rice type $(F=20.58$; $\mathrm{df}=2,80$; $P<0.002)$, sampling date $(F=169.99$, $\mathrm{df}=8,80, P<$ $0.001)$, and the interaction of rice type with sampling date $(F=12.06 ; \mathrm{df}=16,80 ; P=0.027)$. Therefore, was not only in the group of Bt rice TT9-3 and TT9-4 together with non- $B t$ control IR72 (rice type: $F=$ 39.41; df $=2,80 ; P=0.001$; sampling date: $F=49.79$; $\mathrm{df}=2,80 ; P<0.001$; rice type $\times$ sampling date interaction: $F=4.93$; df $=16,80 ; P<0.001)$, but also in the group of $B t$ rice KMD1 and KMD2 together with non- $B t$ control Xiushuil1 (rice type: $F=2.91$; $\mathrm{df}=$ 2,80; $P=0.001$; sampling date: $F=109.946$; $\mathrm{df}=8,80$; $P<0.001$; rice type $\times$ sampling date interaction: $F=$ 5.69; df $=16,80 ; P<0.001)$

In the field experiment with $B t$ rice $\mathrm{B} 1$ and $\mathrm{B} 6$, there was a marked tendency that there were less $S$. biformis individuals collected in the $B t$ plots than in the non- $B t$ plot, particularly for B1 after transplantation at some sampling dates (Fig. 2, left). Likewise, the results of the experiment with $B t$ rice TT9-3 and TT9-4 showed that less $S$. biformis individuals were found in the $B t$ plots at some sampling dates (Fig. 3, left). Similarly, the results of the experiment with $B t$ rice KMD1 and KMD2 showed that less $S$. biformis individuals were collected in the $B t$ plots than those in the non- $B t$ plot through the entire rice growing season, with significant differences at some sampling dates (Fig. 4, left).

Regarding the seasonal average density of $S$. biformis over the whole sampling stage, it was lower in all $B t$ rice plots in comparison with non-Bt plots in most cases (Table 4). In comparison with their respective non- $B t$ controls, the seasonal average density of larvae and adults on $B t$ rice B1, B6, TT9-3, TT9-4, KMD1, and KMD2 was decreased by 38.85, 19.97, 50.52, 51.95, 34.67 , and $55.50 \%$, respectively, which was not correlated with the corresponding mean concentrations of $B t$ insecticidal protein in rice leaves (seedling stage: $r=$ $0.2180<r_{0.05}=0.8114$; tillering stage: $r=0.1645<$ $r_{0.05}=0.8114$ ) and thrips (seedling stage: $r=$ $0.0369<r_{0.05}=0.8114$; tillering stage: $r=0.0784<$ $\left.r_{0.05}=0.8114\right)$. In Bt rice $\mathrm{B} 1$ and $\mathrm{B} 6$ plots, the density of S. biformis larvae or adults and their total density were significantly lower than those in non-Bt plot expect of S. bifromis adults on B6 (Table 4). Similarly, either in Bt rice TT9-3 and TT9-4 plots or in Bt rice KMD1 and KMD2 plots, the density of S. biformis larvae or adults and their total density were all significantly lower than those in non-Bt plot (Table 4).

Field Population Density Sampled Using the Beat Plate Method. Data from the beat plate samplings also showed that the temporal patterns of population changes of S. biformis were similar in the Bt and non-Bt plots, although there was a significant difference in the density of the thrip at some sampling dates for each 

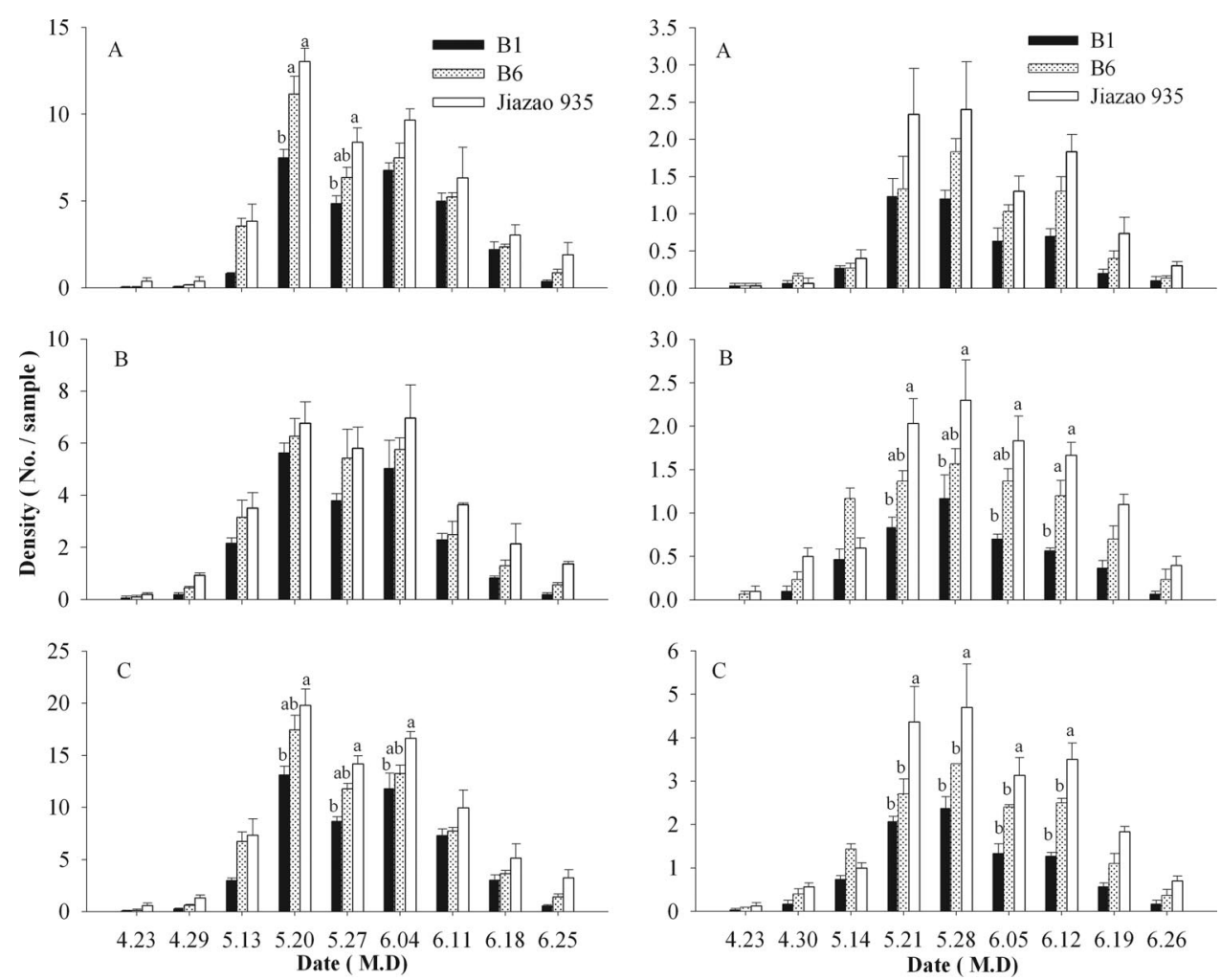

Fig. 2. Mean $\pm \mathrm{SE}$ number of $S$. biformis collected by the plastic bag method (left) and the beat plate method (right) in Bt (indica B1 and B6 expressing CrylAb protein) and non-Bt plots at Hangzhou, China. $n=3$. The samplings were conducted in the seedling bed field on 23 and 29 April and in the transplanted field since 13 May. On the same sampling date, columns capped with different lowercase letters are significantly different (repeated-measured ANOVA, Tukey's multiplerange test, $P<0.05$ ). In both sides: (A) Larval number; (B) Adult number; (C) Total number of larvae and adults.

group with $B t$ rice lines and their respective non- $B t$ control (Figs. 2-4, right). In the group of $B t$ rice B1 and B6 together with non-Bt control Jiazao 935, the density of S. biformis population was significantly affected by rice type $(F=31.33 ; \mathrm{df}=2,80 ; P<0.001)$, sampling date $(F=53.60 ; \mathrm{df}=8,80 ; P<0.001)$, and the interaction of rice type with sampling date $(F=2.76$; $\mathrm{df}=16,80 ; P=0.003)$. Similarly, rice type, sampling date and the interaction of rice type with sampling date significantly affected the density of S. biformis population not only in the group of $B t$ rice TT9-3 and TT9-4 together with non- $B t$ control IR72 (rice type: $F=55.20 ; \mathrm{df}=2,80 ; P=0.001 ;$ sampling date: $F=11.78$; df $=8,80 ; P=0.001$; rice type $\times$ sampling date interaction: $F=2.60 ; \mathrm{df}=16,80 ; P<0.006)$, but also in the group of $B t$ rice KMD1 and KMD2 together with non- $B t$ control Xiushuill (rice type: $F=15.40$; $\mathrm{df}=$ 2,80; $P=0.004$; sampling date: $F=35.47 ; \mathrm{df}=8,80 ; P<$ 0.001 ; rice type $\times$ sampling date interaction: $F=1.90$; $\mathrm{df}=16,80 ; P=0.044)$.

In the field experiment with $B t$ rice $\mathrm{B} 1$ and $\mathrm{B} 6, S$. biformis there were less individuals collected in the $B t$ plots than in the non- $B t$ plot through the whole rice growing stage, with significant differences at most of the sampling dates, particularly for adult number and total number of larvae and adults after transplantation
(Fig. 2, right). Likewise, the pattern was also found in the TT9-3 and TT9-4 field trial, in which there were significantly less S. biformis individuals collected than in the non-Bt plot at several sampling dates, particularly at the seedling stage and the first stage after transplantation (Fig. 3, right). For the experiment with KMD1 and KMD2, there were less S. biformis individuals collected in the $B t$ plots than in the non- $B t$ plot, with significant differences at several sampling dates (Fig. 4, right).

Stenchaetothrips biformis seasonal average densities detected using beat plate sampling over the whole sampling stage were lower on all Bt rice lines in most cases (Table 4). In comparison with their respective non- $B t$ controls, the seasonal average density of larvae and adults on Bt rice B1, B6, TT9-3, TT9-4, KMD1, and KMD2 was reduced by $56.34,27.33,58.03,62.04,34.32$, and $50.49 \%$, respectively, which was not correlated with the concentration of $B t$ insecticidal protein in rice leaves (seedling stage: $r=0.5493<r_{0.05}=0.8114$; tillering stage: $r=0.5410<r_{0.05}=0.8114$ ) and thrips (seedling stage: $r=0.4656<r_{0.05}=0.8114$; tillering stage: $\left.r=0.3925<r_{0.05}=0.8114\right)$. In $B t$ rice $\mathrm{B} 1$ and B6 plots, the density of S. biformis larvae or adults and their total density were significantly lower than those in the non-Bt plot (Table 4). In contrast, in Bt rice 

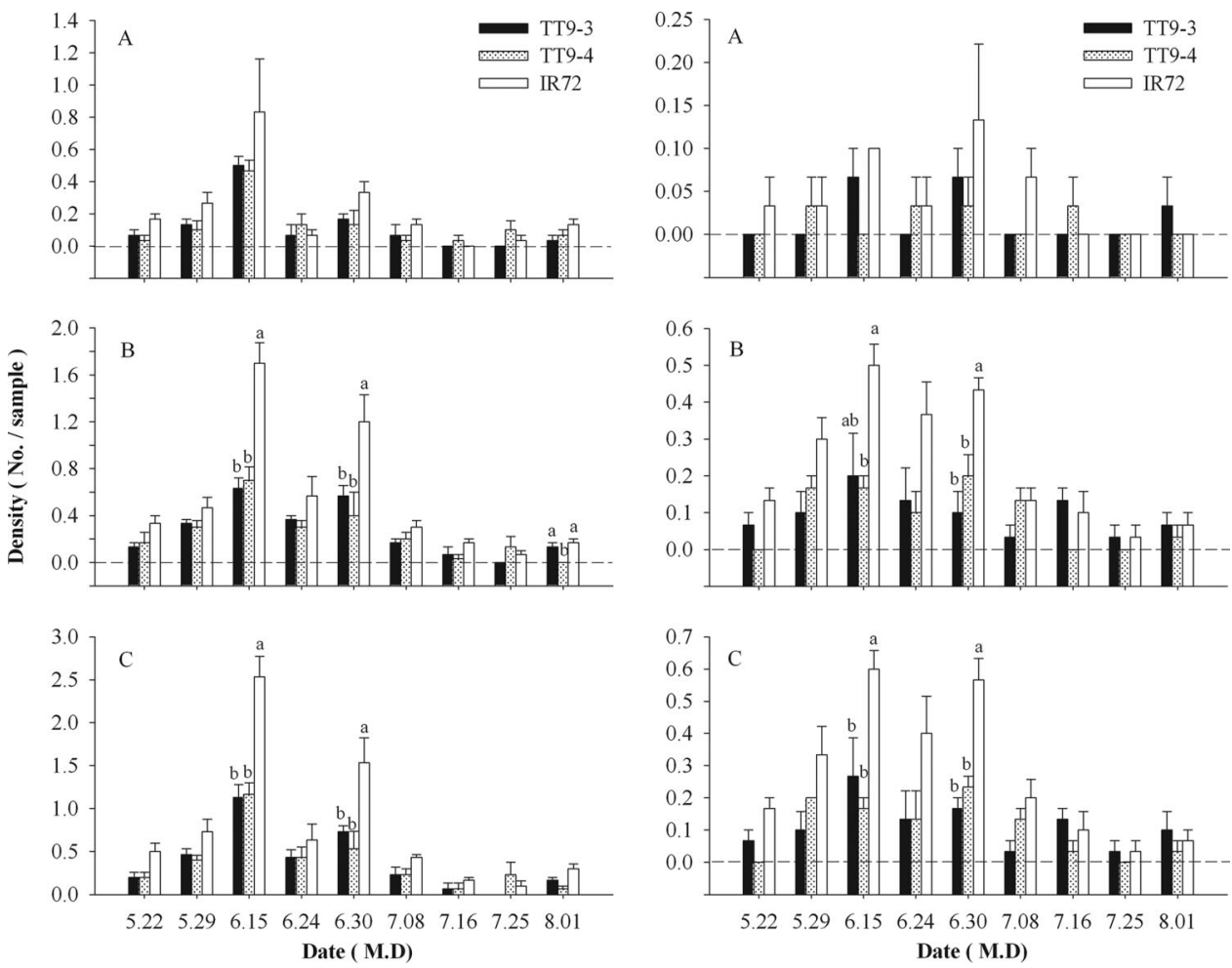

Fig. 3. Mean \pm SE number of $S$. biformis collected by the plastic bag method (left) and the beat plate method (right) in Bt (indica TT9-3 and TT9-4 expressing a fusion of protein CrylAb/CrylAc) and non-Bt plots at Hangzhou, China. $n=$ 3. The samplings were conducted in the seedling bed field on 22 and 29 May and in the transplanted field since 15 June. On the same sampling date, columns capped with different lowercase letters are significantly different (repeated-measured ANOVA, Tukey's multiple-range test, $P<0.05$ ). In both sides: (A) Larval number; (B) Adult number; (C) Total number of larvae and adults.

TT9-3 and TT9-4 plots, the density of S. biformis larvae or adults and their total density were significantly lower than those in non-Bt plot except for $S$. bifromis larvae on TT9-3 (Table 4). Similarly, in Bt rice KMD1 and KMD2 plots, the density of S. biformisr larvae and adults, adults were significantly lower, whereas larvae were not significantly different compared with the control (Table 4).

\section{Discussion}

These studies clearly indicated that $B t$ insecticidal protein (CrylAb or CrylAb/CrylAc) expressed in $B t$ rice leaves is transferred from $B t$ rice to the herbivore S. biformis. These results were in agreement with previous reports that $B t$ insecticidal protein could be detected in Bt rice-fed N. lugens (Bernal et al. 2002, Chen et al. 2005) and in Bt rice-fed C. medinalis (Chen et al. 2009). Similarly, $B t$ insecticidal protein could also be transferred from $B t$ maize to nontarget herbivores such as the aphid Rhopalosiphum padi L. (Hemiptera: Aphididae) (Raps et al. 2001) and the thrip Frankliniella tenuicornis (Uzel) (Thysanoptera: Thripidae) (Obrist et al. 2005). Our results also showed that the concentration of $B t$ insecticidal protein in $B t$ rice-fed S. biformis positively increased with an increase in the concentration of $B t$ insecticidal protein in $B t$ rice leaves. However, these results indicated that there were no significant correlations between some important biological parameters (including prolonged rate of total development duration, decreased rate of fecundity, and seasonal average density of S. biformis on $B t$ rice) and concentrations of $B t$ insecticidal protein detected either in $B t$ rice leaves or in thrips. In some cases, it is inferred that the differences in biological parameters of insects measured between $B t$ rice lines and their respective controls are not directly caused by $B t$ insecticidal protein in $B t$ rice. Therefore, there is a crucial need for further studies to understand it clearly.

Based on former laboratory studies, it has been ascertained that the performance of nontarget sucking insects on $B t$ rice can be classified into three cases, depending on the $B t$ lines tested and insect species evaluated. In the first case, no marked effects on nontarget sucking insects were detected. For example, none of the development and reproduction parameters were differed when measured in the brown planthopper, N. lugens, and the white-backed planthopper, S. furcifera reared on Bt rice MSA and MSB expressing a fusion protein of CrylAb/CpTI and non-Bt rice (Fu et al. 2003). Similarly, there was no 

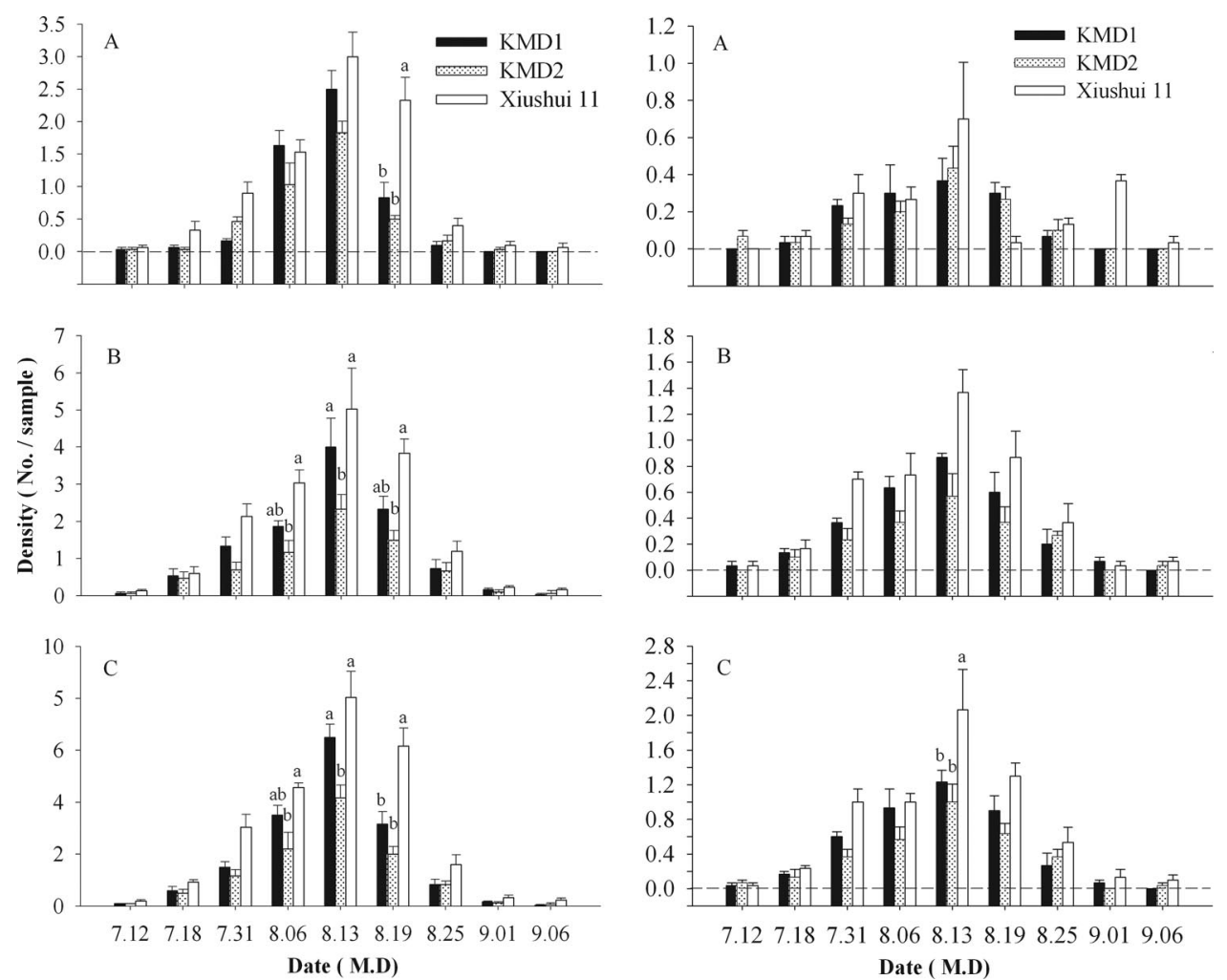

Fig. 4. Mean \pm SE number of $S$. biformis collected by the plastic bag method (left) and the beat plate method (right) in Bt (japonica KMD1 and KMD2 expressing Cry1Ab protein) and non-Bt plots at Hangzhou, China. $n=3$. The samplings were conducted in the seedling bed field on 12 and 18 July and in the transplanted field since 31 July. On the same sampling date, columns capped with different lowercase letters are significantly different (repeated-measured ANOVA, Tukey's multiple-range test, $P<0.05$ ). In both sides: (A) Larval number; (B) Adult number; (C) Total number of larvae and adults.

difference in any of the five fitness parameters (survival to the adult stage, male and female weight, and male and female developmental time) between $N$. lugens reared on $B t$ rice and control lines (Bernal et al. 2002). Tan et al. (2006) also reported that Bt rice B1 and $\mathrm{B} 6$ significantly affect neither oviposition behavior nor fecundity of the white-backed planthopper. In the second case, negative effects on sucking insects were observed. For instance, less feeding and lower fecundity were found when the brown planthopper was fed on Bt rice TT9-3 and TT9-4 (Chen et al. 2003), as well as on KMD1 and KMD2 (Chen 2004). Chen et al. (2004) reported that less feeding on Bt rice $\mathrm{B} 1$ and B6 as well as MSA was observed for brown planthoppers, although no lower fecundity was observed. Similarly, Zhou et al. (2006) showed that the oviposition

Table 4. Seasonal densities of $S$. biformis collected from $B t$ and non-Bt plots across the entire sampling period at Hangzhou, China

\begin{tabular}{|c|c|c|c|c|c|c|}
\hline \multirow{2}{*}{ Rice genotype } & \multicolumn{3}{|c|}{ Sampled by the plastic bag method } & \multicolumn{3}{|c|}{ Sampled by the beat plate method } \\
\hline & Larvae & Adults & Total & Larvae & Adults & Total \\
\hline \multicolumn{7}{|l|}{ Group 1 (indica) } \\
\hline $\mathrm{Bl}(\mathrm{CrylAb})$ & $3.07 \pm 0.56 \mathrm{c}$ & $2.25 \pm 0.41 b$ & $5.32 \pm 0.95 \mathrm{c}$ & $4.93 \pm 0.93 \mathrm{~b}$ & $4.74 \pm 0.79 \mathrm{c}$ & $9.67 \pm 0.16 \mathrm{c}$ \\
\hline B6 (CrylAb) & $4.14 \pm 0.71 \mathrm{~b}$ & $2.84 \pm 0.47 \mathrm{ab}$ & $6.98 \pm 1.15 b$ & $7.22 \pm 1.32 b$ & $8.78 \pm 1.13 \mathrm{~b}$ & $16.00 \pm 0.23 b$ \\
\hline Jiazao935 & $5.24 \pm 0.85 \mathrm{a}$ & $3.48 \pm 0.50 \mathrm{a}$ & $8.70 \pm 1.32 \mathrm{a}$ & $10.44 \pm 1.98 \mathrm{a}$ & $11.70 \pm 1.62 \mathrm{a}$ & $22.15 \pm 3.48 \mathrm{a}$ \\
\hline \multicolumn{7}{|l|}{ Group 2 (indica) } \\
\hline TT9-3 (CrylAb/CrylAc) & $1.15 \pm 0.31 b$ & $2.67 \pm 0.44 \mathrm{~b}$ & $3.81 \pm 0.70 \mathrm{~b}$ & $0.19 \pm 0.08 \mathrm{ab}$ & $0.96 \pm 0.20 \mathrm{~b}$ & $1.15 \pm 0.22 b$ \\
\hline TT9-4 (CrylAb/CrylAc) & $1.22 \pm 0.29 \mathrm{~b}$ & $2.48 \pm 0.47 \mathrm{~b}$ & $3.70 \pm 0.70 b$ & $0.15 \pm 0.07 \mathrm{~b}$ & $0.89 \pm 0.18 b$ & $1.04 \pm 0.20 \mathrm{~b}$ \\
\hline IR72 & $2.19 \pm 0.57 \mathrm{a}$ & $5.52 \pm 1.06 \mathrm{a}$ & $7.70 \pm 1.51 \mathrm{a}$ & $0.44 \pm 0.13 \mathrm{a}$ & $2.30 \pm 0.35 \mathrm{a}$ & $2.74 \pm 0.43 \mathrm{a}$ \\
\hline \multicolumn{7}{|l|}{ Group 3 (japonica) } \\
\hline KMD1 (CrylAb) & $5.93 \pm 1.72 b$ & $12.30 \pm 2.59 \mathrm{~b}$ & $18.22 \pm 4.11 \mathrm{~b}$ & $1.44 \pm 0.34 \mathrm{a}$ & $3.22 \pm 0.61 b$ & $4.67 \pm 0.91 \mathrm{~b}$ \\
\hline KMD2 (CrylAb) & $4.56 \pm 1.20 \mathrm{~b}$ & $7.85 \pm 1.54 \mathrm{~b}$ & $12.41 \pm 2.65 b$ & $1.37 \pm 0.31 \mathrm{a}$ & $2.15 \pm 0.44 b$ & $3.52 \pm 0.69 b$ \\
\hline Xiushuill & $9.70 \pm 2.08 \mathrm{a}$ & $18.19 \pm 3.54 \mathrm{a}$ & $27.89 \pm 5.47 \mathrm{a}$ & $2.30 \pm 0.53 \mathrm{a}$ & $4.81 \pm 0.92 \mathrm{a}$ & $7.11 \pm 1.37 \mathrm{a}$ \\
\hline
\end{tabular}

In the parentheses is the type of $B t$ protein expressed by the rice line. Data are means $\pm \mathrm{SE}(n=3)$. Values followed by different lowercase letters within a column for each group are significantly different (repeated-measured ANOVA, $P<0.05$ ). 
period was shorter on $B t$ rice KMD1 and KMD2, and fecundity was lower on KMD2 but not on KMD1 for white-backed planthoppers. In the third case, positive effects on sucking insects were found as reported by Zhou et al. (2005); the green leafhopper N. cincticeps actually performed better on $B t$ rice KMD1 and KMD2, resulting from a longer oviposition period and higher net reproductive rate on $B t$ rice KMD1 and KMD2.

Our results concur with the studies in the second case described above. It is clear that among three groups of $B t$ rice lines, some of the genotypes showed detrimental effects on $S$. biformis, resulting in longer total development duration of larvae and pupae and preoviposition period, shorter oviposition period and female adult longevity, and lower fecundity. To summarize this and previous studies (Chen et al. 2003), it is clear that our tested $B t$ rice lines, namely, KMD1, KMD2, TT9-3, and TT9-4, showed negative impacts on the two sucking species, brown planthoppers and $S$. biformis, particularly on their fecundity. These observed differences might result from the differences in chemical constituents or nutrition of different $B t$ rice (Faria et al. 2007) and not because of direct effects of $B t$ insecticidal protein in $B t$ rice. Certainly, the real cause of the differences calls for further study.

In comparison with the laboratory experiments, our previous multiple year-site studies showed that there were no significant difference in the population density of brown planthoppers, white-backed planthoppers, and green leafhoppers on $B t$ rice (B1 and $\mathrm{B} 6$, TT9-3, TT9-4, KMD1, and KMD2) and on their non-Bt corresponding controls at various sites (Liu et al. 2002, 2003; Chen et al. 2006b, 2007; Li et al. 2007). Likewise, various $B t$ rice lines with a fusion protein of CrylAb/ CpTI (MSA, MSB, MSA4) and their derived hybrid rice lines (21S/MSB, II-32A/MSB, and KF6-304) did not result in consequently higher densities of brown planthoppers, white-backed planthoppers, and green leafhoppers or rice gall midge Orseolia oryzae (WoodMason) (Diptera: Cecidomyiidae) compared with their non-Bt parental control MH86 (Fu et al. 2003, Liu et al. 2007). Conversely, Zhou et al. (2005) reported that the population density of green leafhoppers on $B t$ rice KMD2 were significantly higher than on non- $B t$ control Xiushuil1, which might be because of the smaller testing field area ( 17.5 by $25.0 \mathrm{~m}$ in total), different sampling method, and insect species tested. In this study, we found that six Bt rice lines tested, in general, showed negative effects on S. biformis populations and resulted in lower densities through the entire rice growth stage in the $B t$ rice fields in comparison with the non- $B t$ controls. Thus, we infer that the $B t$ rice lines we evaluated will not cause a higher occurrence of $S$. biformis population in $B t$ rice fields. This conclusion completely agrees with the previous field results that $B t$ rice was unlikely to promote a greater occurrence of nontarget sucking insects in the field, as described above except by Zhou et al. (2005). Additionally, through summarizing previous studies and this study, it is clear that field experiments should be carried out when detrimental effects were found in laboratory studies to assess the impact of $B t$ rice on nontarget arthropods according to the tiered scheme of ecological risk assessment for transgenic crops to nontarget arthropods (Romeis et al. 2008). Furthermore, the results of the field experiments probably should be considered more important and reliable than laboratory studies when discrepancies existed between laboratory and field studies (such as TT9-3, TT9-4, and KMD1).

Based on the literature, the impacts of $B t$ rice on the performance of nontarget sucking insects could be negligible, negative, or positive, depending on the $B t$ rice lines and insect species evaluated. These quite controversial conclusions on effects of $B t$ rice on nontarget insects were also encountered with $B t$ maize (Zea mays L.). In one study, the aphid Rhopalosiphum maidis (Fitch) (Hemiptera: Aphididae) was found to perform considerably better on six $B t$ maize lines expressing CrylAb than on the near isogenic respective lines, resulting in exceptionally higher numbers on these Bt plants (Faria et al. 2007). Other studies, however, showed that there were no effects of $B t$ maize on aphids (Head et al. 2001, Raps et al. 2001, Bourguet et al. 2002, Dutton et al. 2002). Similarly, performance by thrips, F. tenuicornis (Uzel) and Anaphothrips obscurus (Muller) (Thysanoptera: Thripidae), in their study was not significantly different between $B t$ and non- $B t$ maize in studies by Zwahlen et al. (2000), Obrist et al. (2005), but thrips density was significantly higher in $B t$ maize in the study of Bourguet et al. (2002). In the light of these few studies of transgenic crops, it is obvious that we must try to sort out case-by-case studies of nontarget arthropods on transgenic crops.

To ensure $B t$ crops are compatible with other tactics of integrated pest management (IPM), the susceptibility of $B t$ crops to nontarget pest such as planthoppers, leafhoppers and thrips on $B t$ rice need to be considered. It will be desirable if $B t$ crop lines have a negligible or unfavorable impact on nontarget pest in comparison with their non- $B t$ isogenic lines. Thus, the decreased susceptibility to S. biformis of the six types of $B t$ rice lines tested in this study may be welcome news. In conclusion, it is suggested that our tested $B t$ rice lines are unlikely to enhance the occurrence of $S$. biformis in the rice ecosystem.

\section{Acknowledgments}

We thank Prof. Q. Y. Shu (Zhejiang University, China) and Prof. I. Altosaar (University of Ottawa, Canada) for providing the original seeds of $B t$ rice lines KMD1 and KMD2; a statistical expert, Prof. Q. Y. Tang (Zhejiang University, China), for helping our data analysis; and A. Mohsin (University of Ottawa, Canada) for the critical reading and revising this manuscript. Financial support was received from the National Program on Key Basic Research Projects (973 Program, 2007CB109202), the Ministry of Science and Technology of China, the National Natural Science Foundation of China (30671377), and the Special Research Projects for Developing Transgenic Plants (2008ZX08011-01). 


\section{References Cited}

Bacci, L., M. C. Picanco, M. F. Moura, A. A. Semeao, F. Fernandes, and E.G.F. Morais. 2008. Sampling plan for thrips (Thysanoptera: Thripidae) on cucumber. Neotropical Entomol. 37: 582-590.

Bai, Y. Y., M. X. Jiang, J. A. Cheng, and D. Wang. 2006. Effects of CrylAb toxin on Propylea japonica (Thunberg) (Coleoptera: Coccinellidae) through its prey, Nilaparvata lugens Stål (Homoptera: Delphacidae), feeding on transgenic Bt rice. Environ. Entomol. 35: 130-136.

Bashir, K., T. Husnain, and S. Riazuddin. 2004a. Response of transgenic rice expressing two $B t$ genes to nontarget insect. Int. Rice Res. Notes 29: 15-16.

Bashir, K., T. Husnain, T. Fatima, Z. Latif, S. A. Mehdi, and S. Riazuddin. 2004b. Field evaluation and risk assessment of transgenic indica basmati rice. Mol. Breed. 13: 301-312.

Bashir, K., T. Husnain, T. Fatima, N. Riaz, R. Makhdoom, and S. Riazuddin. 2005. Novel indica basmati line (B-370) expressing two unrelated Bacillus thuringiensis genes is highly resistant to two lepidopterans in the field. Crop Protect. 24: 870-879.

Bernal, C. C., R. M. Aguda, and M. B. Cohen. 2002. Effect of rice lines transformed with Bacillus thuringiensis toxin genes on the brown planthopper and its predator Cyrtorhinus lividipennis. Entomol. Exp. Appl. 102: 21-28.

Bourguet, D., J. Chaufaux, A. Micoud, M. Delos, B. Naibo, F. Bombarde, G. Marque, N. Eychenne, and C. Pagliari. 2002. Ostrinia nubilalis parasitism and the field abundance of non-target insects in transgenic Bacillus thuringiensis corn (Zea mays). Environ. Biosafety Res. 1: 49-60.

Breitler, J. C., J. M. Vassal, M. D. Catala, D. Meynard, V. Marfà, E. Melé, M. Royer, I. Murillo, B. San Segundo, E. Guiderdoni, and J. Messeguer. 2004. Bt rice harbouring cry genes controlled by a constitutive or wound-inducible promoter: protection and transgene expression under Mediterranean field conditions. Plant Biotechnol. J. 2: 417-430.

Chen, H., G. Zhang, Q. Zhang, and Y. Lin. 2008. Effect of transgenic Bacillus thuringiensis rice lines on mortality and feeding behavior of rice stem borers (Lepidoptera: Crambidae). J. Econ. Entomol. 101: 182-189.

Chen, M. 2004. Ecological safety assessments of transgenic rice with insect or virus resistance on their non-target organisms. PhD dissertation, Zhejiang University, Hnagzhou, China.

Chen, M., G. Y. Ye, C. Hu, and S. K. Datta. 2003. Effects of transgenic Bt indica rice on the feeding and oviposition behavior of the planthoppers, Nilaparvata lugens. Acta Phytophyl. Sin. 30: 366-370.

Chen, M., G. Y. Ye, H. W. Yao, C. Hu, and Q. Y. Shu. 2004. Evaluation of the impacts of insect-resistant transgenic rice on the feeding and oviposition behavior of its nontarget insect, the brown planthoppers, Nilaparvata lugens (Homoptera: Delphacidae). Sci. Agric. Sin. 37: 222-226.

Chen, M., J. Z. Zhao, G. Y. Ye, Q. Fu, and A. M. Shelton. 2006a. Impact of insect-resistant transgenic rice on target insect pests and non-target arthropods in China. Insect Sci. 13: 409-420.

Chen, M., G. Y. Ye, Z. C. Liu, H. Y. Yao, X. X. Chen, Z. C. Sheng, C. Hu, and S. K. Datta. 2006b. Field assessment of the effects of transgenic rice expressing a fused gene of $c r y 1 A b$ and crylAc from Bacillus thuringiensis Berliner on nontarget planthoppers and leafhoppers. Environ. Entomol. 35: 127-134.

Chen, M., G. Y. Ye, X. M. Lu, C. Hu, Y. F. Peng, Q. Y. Shu, and I. Altosaar. 2005. Biotransfer and bioaccumulation of CrylAb insecticidal protein in rice plant brown plan- thopper-wolf spider food chain. Acta Entomol. Sin. 48: $208-213$.

Chen, M., G. Y. Ye, Z. C. Liu, Q. Fang, C. Hu, Y. F. Peng, and A. M. Shelton. 2009. Analysis of CrylAb toxion bioaccumulation in a food chain of $\mathrm{Bt}$ rice, an herbivore and a predator. Ecotoxicology 18: 230-238.

Chen, M., Z. C. Liu, G. Y. Ye, Z. C. Shen, C. Hu, Y. F. Peng, I. Altosaar, and A. M. Shelton. 2007. Impacts of transgenic $c r y l A b$ rice on non-target planthoppers and their main predator Cyrtorhinus lividipennis (Hemiptera: Miridae) - a case study of the compatibility of $B t$ rice with biological control. Biol. Control 42: 242-250.

Cohen, M. B., M. Chen, J. S. Bentur, K. L. Heong, and G. Y. Ye. 2008. Bt rice in Asia: potential benefits, impact, and sustainability, pp. 223-248. In J. Romeis, A. M. Shelton, and G. G. Kennedy (eds.), Integration of insect-resistant genetically modified crops within IPM systems. Springer, New York.

Dale, D. 1994. Insect pests of the rice plant-their biology and ecology, pp. 363-485. In E. A. Heinrichs (ed.), Biology and management of rice insects. Wiley Eastern/ New Age International Limited, New Delhi, India.

Dutton, A., H. Klein, J. Romeis, and F. Bigler. 2002. Uptake of Bt-toxin by herbivores feeding on transgenic maize and consequences for the predator Chrysoperla carnea. Ecol. Entomol. 27: 441-447.

Faria, C. A., F. L. Wäckers, J. Pritchard, D. A. Barrett, and T.C.J. Turlings. 2007. High susceptibility of $B t$ maize to aphids enhances the performance of parasitoids of lepidopteran pests. PLoS One 7: e600.

Fu, Q., F. Wang, D. H. Li, Q. Yao, F. X., Lai, and Z. T. Zhang. 2003. Effects of insect resistant transgenic rice lines MSA and MSB on non-target pests Nilaparvata lugens and Sogatella furcifera. Acta Entomol. Sin. 46: 697-704.

Han, L., K. Wu, Y. Peng, F. Wang, and Y. Guo. 2007. Efficacy of transgenic rice expressing Cry $1 \mathrm{Ac}$ and CpTI against the rice leaffolder, Cnaphalocrocis medinalis (Guenée). J. Invertebr. Pathol. 96: 71-79.

Head, G., C. R. Brown, M. E. Groth, and J. J. Duan. 2001. CrylAb protein levels in phytophagous insects feeding on transgenic corn: implications for secondary exposure risk assessment. Entomol. Exp. Appl. 99: 37-45.

High, S. M., M. B. Cohen, Q. Y. Shu, and I. Altosaar. 2004. Achieving successful deployment of $B t$ rice. Trends Plant Sci. 9: 286-292.

Hsu, Z. Y., J. D. Li, C. H. Chang, and Z. C. Hu. 1978. Studies on the thrips infesting rice in Jin-Ping of Kweichow province. Acta Entomol. Sin. 21: 13-21.

Husain, M. 1982. Rice thrips in Mymensingh Bangladesh. Int. Rice Res. Newsl. 7: 16.

Joost, P. H., and D. G. Riley. 2004. Sampling techniques for thrips (Thysanoptera: Thripidae) in preflowering tomato. J. Econ. Entomol. 97: 1450-1454.

Khush, G. S. 2005. What it will take to feed 5.0 billion rice consumers in 2030. Plant Mol. Biol. 59: 1-6.

Li, F. F., G. Y. Ye, Q. Wu, Y. F. Peng, and X. X. Chen. 2007. Arthropod abundance and diversity in $B t$ and non- $B t$ rice fields. Environ. Entomol. 36: 646-654.

Liu, Y. F., L. He, Q. Wang, S. Q. Hu, W. H. Liu, and K. G. Chen. 2007. Effects of and ecological safety insect-resistant $c r y 1 A c / s c k$ transgenic rice on key non-target pests in paddy fields. Sci. Agric. Sin. 40: 1181-1189.

Liu, Z. C., G. Y. Ye, C. Hu, and S. K. Datta. 2002. Effects of $B t$ transgenic rice on population dynamics of main nontarget insect pests and dominant spider species in rice paddies. Acta. Phytophyl. Sin. 29: 138-144.

Liu, Z. C., G. Y. Ye, C. Hu, and S. K. Datta. 2003. Impact of transgenic indica rice with a fused gene of $c r y 1 A b / c r y 1 A c$ 
on the rice paddy arthropod community. Acta Entomol. Sin. 46: 454-465.

Marvier, M., C. McCreedy, J. Regetz, and P. Kareival. 2007. A meta-analysis of effects of $B t$ cotton and maize on nontarget invertebrates. Science 316: 1475-1477.

Moura, M. F., M. C. Picanço, E. M. Silva, R.N.C. Guedes, and J. L. Pereira. 2003. Plano de amostragem do biótipo B de Bemisia tabaci na cultura do pepino. Pesq. Agropec. Bras. 38: 1-7.

Nugaliyadde, L., and E. A. Heinrichs. 1984. Biology of rice thrips, Stenchaetothrips biformis (Bagnall) (Thysanoptera: Thripidae), and a greenhouse rearing technique. J. Econ. Entomol. 77: 1171-1175.

O’Callaghan, M., T. R. Glare, E.P.J. Burgess, and L. A. Malone. 2005. Effects of plants genetically modified for insect resistance on nontarget organisms. Annu. Rev. Entomol. 50: 271-292.

Obrist, L. B., H. Klein, A. Dutton, and F. Bigler. 2005. Effects of Bt maize on Frankliniella tenuicornis and exposure of thrips predators to prey-mediated $B t$ toxin. Entomol. Exp. Appl. 115: 409-416.

Pathak, M. D., and Z. R. Khan. 1994. Insect pests of rice. International Rice Research Institute, Manila, Philippines.

Rahman, M. U., H. Rashid, A. A. Shahid, K. Bashir, T. Husnain, and S. Riazuddin. 2007. Insect resistance and risk assessment studies of advanced generations of basmati rice expressing two genes of Bacillus thuringiensis. Electronic J. Biotechnol. 10: 240-251.

Ramesh, S., D. Nagadhara, I. C. Pasalu, A. P. Kumari, N. P. Sarma, V. D. Reddya, and K. V. Rao. 2004. Development of stem borer resistant transgenic parental lines involved in the production of hybrid rice. J. Biotechnol. 111: 131141.

Raps, A., J. Kehr, P. Gugerli, W. J. Moar, F. Bigler, and A. Hilbeck. 2001. Immunological analysis of phloem sap of Bacillus thurigiensis corn and of the nontarget herbivore Rhopalosiphum padi (Homoptera: Aphididae) for the presence of Cry1Ab. Mol. Ecol. 10: 525-533.

Riaz, N., T. Husnain, T. Fatima, R. Makhdoom, K. Bashir, L. Masson, I. Altosaar, and S. Riazuddin. 2006. Development of indica Basmati rice harboring two insecticidal genes for sustainable resistance against lepidopteran insects. South Afr. J. Botany 72: 217-223.

Romeis, J., D. Bartsch, F. Bigler, M. P. Candolfi, M.M.C. Gielkens, S. E. Hartley, R. L. Hellmich, J. E. Huesing, P. C. Jepson, R. Layton, et al. 2008. Assessment of risk of insect-resistant transgenic crops to nontarget arthropods. Nat. Biotechnol. 26: 203-208.

SAS Institute. 1996. PROC user's manual, version 6th ed SAS Institute, Cary, NC.

Shelton, A. M., J. Z. Zhao, and R. T. Roush. 2002. Economic, ecological, food safety, and social consequences of the deployment of Bt transgenic plants. Annu. Rev. Entomol. 47: 845-881.

Shu, Q. Y., G. Y. Ye, H. R. Cui, X. Y. Cheng, Y. B. Xiang, D. X. Wu, M. W. Gao, Y. W. Xia, C. Hu, R. Sardana, et al. 2000. Transgenic rice plants with a synthetic $c r y l A b$ gene from
Bacillus thuringiensis were highly resistant to eight lepidopteran rice pest species. Mol. Breed. 6: 433-439.

Sisterson, M. S., R. W. Biggs, C. Olson, Y. Carrière, T. J. Dennehy, and B. E. Tabashinik. 2004. Arthropod abundance and diversity in Bt and non-Bt cotton field. Environ. Entomol. 33: 921-929.

Tan, H., G. Y. Ye, J. H. Shen, Y. F. Peng, and C. Hu. 2006. Effects of transgenic indica rice expressing a gene of cry $1 \mathrm{Ab}$ with insect resistance on the development and reproduction of nontarget pest, Sogatella furcifera (Homoptera: Delphacidae). Acta Phytophyl. Sin. 33: 251-256.

Tang, Q. Y., and M. G. Feng. 2007. DPS ${ }^{\odot}$ data processing for practical statistics. Science Press, Beijing, China.

Tang, W., H. Chen, C. Xu, X. Li, Y. Lin, and Q. Zhang. 2006. Development of insect-resistant transgenic indica rice with a synthetic crylC* gene. Mol. Breed. 18: 1-10.

Tian, J. C., Z. C. Liu., H. W. Yao, G. Y. Ye, and Y. F. Peng. 2008. Impact of transgenic rice with a $c r y 1 \mathrm{Ab}$ gene on parasitoid subcommunity structure and the dominant population dynamics of parasitoid wasps in rice paddy. J. Environ. Entomol. 30: 1-7.

Wolfenbarger, L. L., S. E. Naranjo, J. G. Lundgren, R. J. Bitze, and L. S. Watrud. 2008. Bt crop effects on functional guilds of non-target arthropods: a meta-analysis. PLoS One 3: e2118.

Ye, G. Y., Q. Y. Shu, H. W. Yao, H. R. Cui, X. Y. Cheng, C. Hu, Y. W. Xia, M. W. Gao, and I. Altosaar. 2001a. Field evaluation of resistance of transgenic rice containing a synthetic cry $1 A b$ gene from Bacillus thuringiensis Berliner to two stem borers. J. Econ. Entomol. 94: 271-276.

Ye, G. Y., J. M. Tu, H. Cui, K. Datta, and S. K. Datta. 2001 b. Transgenic IR72 with fused Bt gene $c r y 1 A b / c r y l A c$ from Bacillus thuringiensis is resistant against four lepidopteran species under field conditions. Plant Biotechnol. 18: 125133.

Ye, G. Y., H. W. Yao, Q. Y. Shu, X. Y. Cheng, C. Hu, Y. W. Xia, M. W. Gao, and I. Altosaar. 2003. High levels of stable resistance in transgenic rice with a synthetic $c r y 1 A b$ gene from Bacillus thuringiensis Berliner to rice leaffolder, Cnaphalocrocis medinalis (Guenée) under field conditions. Crop Protect. 22: 171-178.

Zhou, X. B., and W. M. Shi. 2007. Effect of root surface iron plaque on Se translocation and uptake by Fe-deficient rice. Pedosphere 17: 580-587.

Zhou, X. B., J. A. Cheng, and Y. G. Lou. 2006. Effects of transgenic cry $1 \mathrm{Ab}$ rice on population development of the white-backed planthopper, Sogatella furcifera (Horvath) (Homoptera: Delphacidae). Acta Entomol. Sin. 49: 786791.

Zhou, X., J. A. Cheng, Y. Hu, and Y. G. Lou. 2005. Effects of transgenic Bt Rice on the population development of Nephotettix cincticeps. Chinese J. Rice Sci. 19: 74-78.

Zwahlen, C., W. Nentwig, F. Bigler, and A. Hilbeck. 2000. Tritrophic interactions of transgenic Bacillus thuringiensis corn, Anaphothrips obscurus (Thysanoptera: Thripidae), and the predator Orius majusculus (Heteroptera: Anthocoridae). Environ. Entomol. 29: 846-850.

Received 25 March 2009; accepted 18 December 2009. 